Research Article

\title{
Rainwater as a Source of Drinking Water: Health Impacts and Rainwater Treatment
}

\author{
Khayan Khayan (D), ${ }^{1}$ Adi Heru Husodo, ${ }^{2}$ Indwiani Astuti, ${ }^{2}$ Sudarmadji Sudarmadji, ${ }^{3}$ \\ and Tjut Sugandawaty Djohan ${ }^{4}$ \\ ${ }^{1}$ Department of Environmental Health, Poltekkes Kemenkes, Pontianak, Indonesia \\ ${ }^{2}$ Medicine Faculty, Universitas of Gadjah Mada, Yogyakarta, Indonesia \\ ${ }^{3}$ Geography Faculty, Universitas of Gadjah Mada, Yogyakarta, Indonesia \\ ${ }^{4}$ Laboratory of Ecology and Conservation, Biology, Faculty, Universitas of Gadjah Mada, Yogyakarta 55281, Indonesia
}

Correspondence should be addressed to Khayan Khayan; mkhayan@yahoo.co.id

Received 16 January 2019; Revised 9 May 2019; Accepted 15 May 2019; Published 11 July 2019

Academic Editor: Issam A. Al-Khatib

Copyright (c) 2019 Khayan Khayan et al. This is an open access article distributed under the Creative Commons Attribution License, which permits unrestricted use, distribution, and reproduction in any medium, provided the original work is properly cited.

\begin{abstract}
Rainwater is the main source of drinking water in tropical communities, especially in West Kalimantan. Air contamination causes rainwater to become acidic and cloudy and adds heavy metals such as $\mathrm{Pb}$ into rainwater. In addition to pollution, the way in which the rainwater is collected such as through zinc roofing also exposes the rainwater to heavy metals. The presence of $\mathrm{Pb}$ in rainwater will have an impact on the health of the community in the long run. The model of simple water treatment using filtration is needed to overcome this problem with the use of media available in the region. The media used are in the form of mollusk sand and activated carbon. In the end, the mollusk sand filtration model and activated carbon sorption were effectively used to filter polluted rainwater to be safe for consumption.
\end{abstract}

\section{Introduction}

The amount of surface water and groundwater in West Kalimantan is abundant, but with respect to quality, it does not meet the requirements of being used as drinking water $[1,2]$. Surface water such as rivers, lakes, and reservoirs has a high turbidity level, and Fe content in groundwater exceeds the threshold value, triggering the usage of rainwater as a source of drinking water [3]. Rainwater is used as a source of drinking water not only in West Kalimantan, Indonesia, but also in other tropical regions, such as Australia and Africa $[4,5]$.

Increasing population and industrial growth have an impact on air quality [6]. As in West Kalimantan, besides the industrialization factor, the condition of peatlands is a contributor to air pollution due to fires in the dry season [7]. Under highly polluted air conditions, the quality of rainwater normally gets affected, for example, increase in the heavy metal content, such as lead $(\mathrm{Pb})[8,9]$.
Before being collected in a water tank, the rainwater will fall on the tin roof used by the community as the roof of the house. In the process of making zinc roofs, each part of the roof is added or coated with $\mathrm{Pb} . \mathrm{Pb}$ serves to strengthen the zinc layer bond with the iron layer [10-12]. Lead is also used to prevent corrosion of the zinc roof. In Pontianak City, it is recognized that rainwater is corrosive because it has aggressive $\mathrm{CO}_{2}$ and low $\mathrm{pH}$ in the range of 4.78-5.85 [13]. So that the tin roof is easily corroded and $\mathrm{Pb}$ as a roof coating also gets dissolved and added into rainwater [14].

Temporal demand for studying the effects of drinking water exposed to lead is attractive because of its toxicological effects, such as kidney disease, cancer, and cognitive impairment from chronic exposure in the short term $[15,16]$. From several studies, the effects of long-term lead exposure have been linked to various forms of cancer, nephrotoxicity, central nervous system effects, and cardiovascular disease in humans. Other effects of $\mathrm{Pb}$ exposure cause enzyme disorders, anemia, mental disorders, and hyperactivity in 
children, underweight and premature conditions in newborns, and increased high blood pressure in adults [10, 11]. In our body, $\mathrm{Pb}$ accumulates in the bone in the long term, around 20-30 years, and becomes chronic [11].

Measurement of $\mathrm{Pb}$ exposure levels in rainwater as a source of drinking water needs to be done as an assessment of health risks by exposure to this heavy metal. Measurement of short-term $\mathrm{Pb}$ health effects can be done by measuring $\mathrm{Pb}$ levels in urine. Our goal is to determine the level of rainwater exposure to $\mathrm{Pb}$ causing health risks and bring about efforts to use rainwater as a safe source of drinking water by applying appropriate technology using media from activated carbon and mollusk sand.

\section{Materials and Methods}

2.1. Study Area and Design. The study was a cross-sectional and experimental study. This cross-sectional study was carried out to analyze the effect of presence of $\mathrm{Pb}$ in urine, while the experimental one was used for testing rainwater treatment devices designed to reduce the content of lead $\mathrm{Pb})$ and turbidity and increase the $\mathrm{pH}$ of rainwater. The treatment is performed using appropriate technology to reduce exposure of rainwater to lead $(\mathrm{Pb})$ through filtering shellfish sand and absorption with activated carbon in a filter tube (Figure 1). Rainwater samples from two target areas in West Kalimantan, Indonesia, were collected to represent urban and rural areas, namely, Pontianak City and Kubu Raya District (Figure 2). In the city, two target locations were chosen, namely, Siantan Hulu and Central Siantan Districts, while in Kubu Raya District, the locations of Limbung village and Arang Limbung village were chosen. This research was conducted for 12 months from January to December 2016.

2.2. Sample Size and Sampling. The sample comes from a group of houses that hold rainwater through a zinc roof as a source of drinking water. A total of 40 houses were sampled in this study. The sampling technique uses simple random clustering with the determination of the sampling done in stages and dividing it into several clusters. The sample area is represented by two target regions. The city is represented by the subdistricts of North Pontianak, and rural area is represented by Sungai Raya District. Rainwater samples were taken at intervals of $0-20$ minutes as much as 2.5 liters of rain. Rainwater samples were taken to meet laboratory requirements, while urine samples were collected from the residents who lived the longest at home with the highest consumption of rainwater.

2.3. Sampling Technique. Water was poured into a $2.5 \mathrm{~mL}$ polyurethane sample bottle during shipment of the sample, tightly closed, and properly labeled to prevent cross contamination. Samples were sent to the laboratory in the form of water samples before processing, and the results of processing using shellfish sand and activated carbon are given in Figure 1. Water parameters such as $\mathrm{pH}$ and turbidity were taken in the field. Samples taken immediately may be brought to the laboratory for testing by inserting into a box containing ice. The samples were collected and processed every time it rained in the area that had been used as the research target. Urine samples were taken from residents of the house who mostly stayed at home and had the highest consumption of rainwater. Urine sample was taken in the morning after wake up. A urine sample was taken to determine the health effects associated with public health problems with a theoretical review.

2.4. Characteristics of Filtration Media. Activated carbon has diverse surface characteristics and pore size distribution, and the characteristics of this activated carbon play an important role in the adsorption of contaminants. Activated carbon used in research is granular or irregular with a size of $0.2-5 \mathrm{~mm}$. Activated carbon is obtained from coconut shell. The manufacturing process starts with the dehydration, the process of removing the water content from the raw material by heating it in an oven at a temperature of $170^{\circ} \mathrm{C}$. At a temperature of around $275^{\circ} \mathrm{C}$, carbon decomposition takes place and tar, methanol, phenol, and other by-products are formed. Nearly $80 \%$ of carbon is obtained at temperatures of $400-600^{\circ} \mathrm{C}$. Charcoal was formed from carbonization at a temperature of more than $400^{\circ} \mathrm{C}$, and activation was carried out chemically using calcium chloride $\left(\mathrm{CaCl}_{2}\right)[17,18]$. The mollusk sand used comes from the coastal area of West Kalimantan. Mollusk sand is the result of weathering the shell of the shellfish. Mollusk sand used is $0.2-5 \mathrm{~mm}$ in size.

2.5. Sample Analysis with Atomic Absorption Spectrophotometer (AAS). Analysis of metals in both water and urine is done using an AAS. The AAS operating procedure is to turn on the AAS tool, then the standard solution and sample are added into the test tube available on the AAS device, the computer AAS device is adjusted, the AAS flame and cathode lamp are turned on, and then the standard solution is aspirated into acetylene air, indicating the resulting measurement reading must be zero by pressing the zero button. In succession, the standard solution was analyzed using an AAS and continued with a blank solution and sample solution (water and sediment). The measurement results of atomic absorption will be recorded and then calculated to get the metal concentration in the sample solution $[19,20]$.

2.6. Data Analysis. Data were analyzed descriptively and analytically. The correlation test was used to analyze the relationship between exposure of rainwater to $\mathrm{Pb}$ and health problems of people who use rainwater as a source of drinking water and to see the strength of the relationship carried out by looking at the value of $r$ [7]. The T-test was used to see the difference in average between treatments, namely, analysis of differences in $\mathrm{Pb}, \mathrm{pH}$ levels, and turbidity between before and after rainwater treatment with mollusk sand filtration and absorption with activated carbon.

2.7. Ethical Considerations. Ethical approval was obtained from the Ethics Committee for Health Research at the 


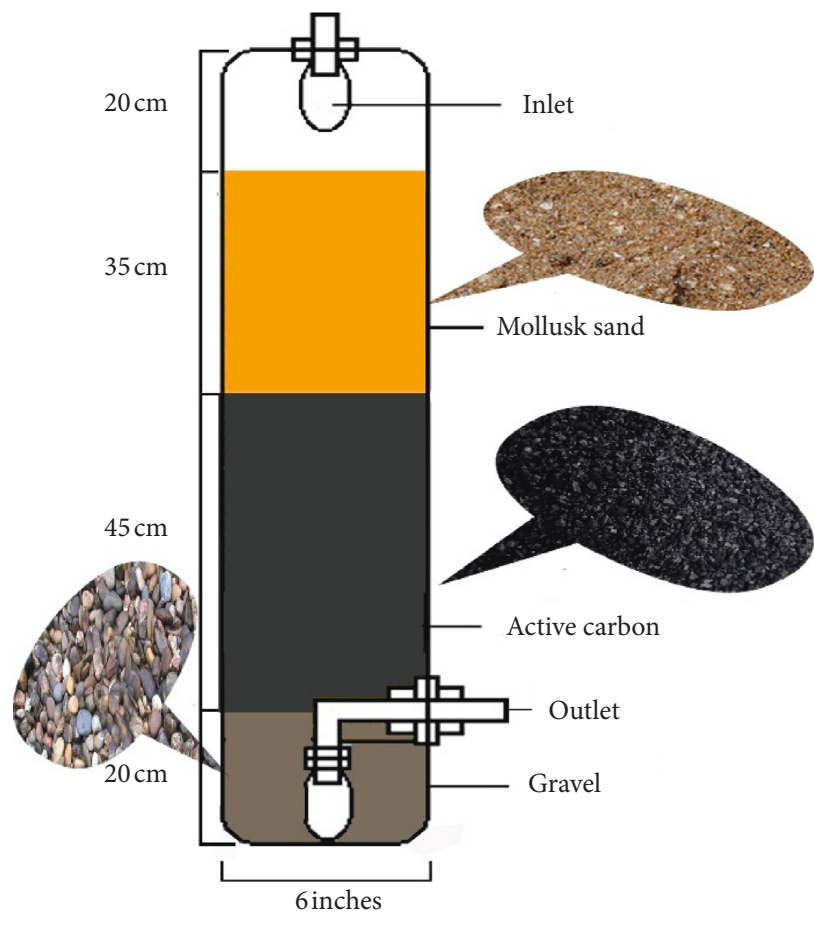

(a)

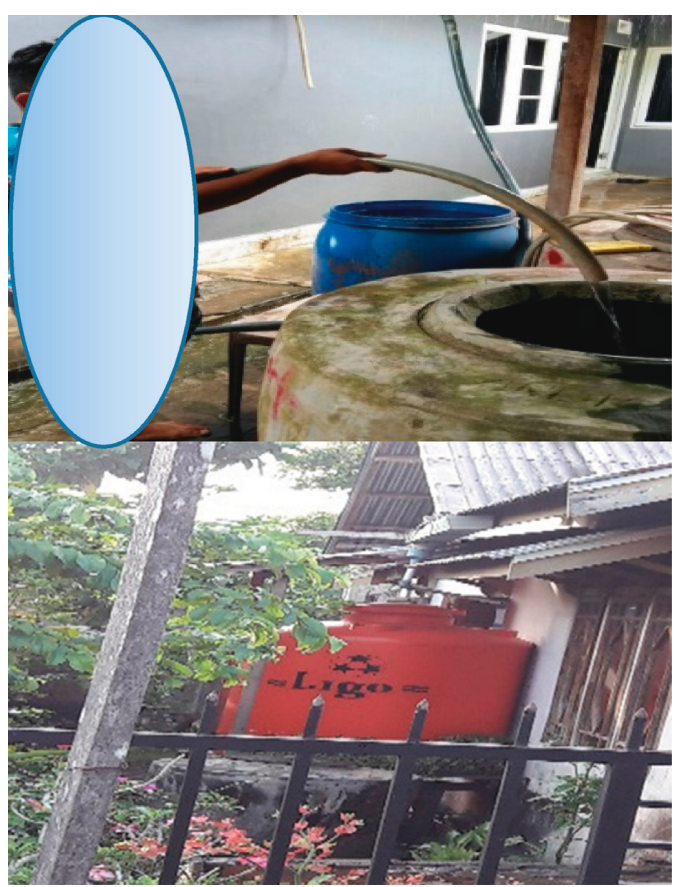

(b)

FIgURE 1: (a) Filtration device with mollusk sand and activated carbon media. (b) The way people collect rainwater.

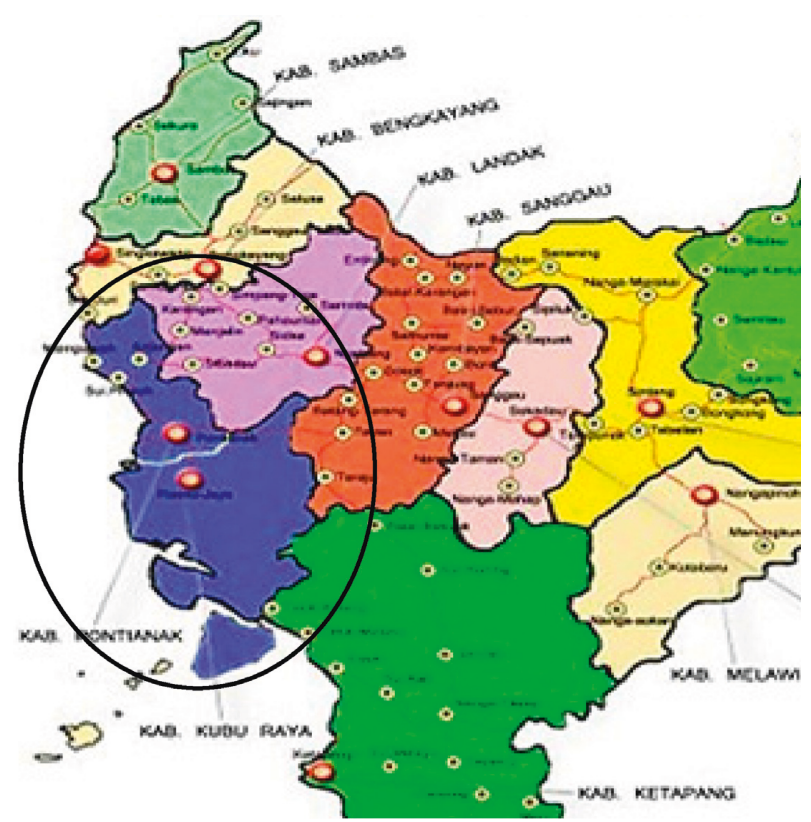

Figure 2: The location of the study conducted.

Makasar Ministry of Health Polytechnic (303/KEPPTKMKS/VII). Permits were also sought from the Pontianak City government and Kubu Raya Regency before the start of the research. Participation in this study was voluntary, and informed consent was obtained from each participant at the time of the study after explaining to them the purpose of the study and how the findings would benefit them.

\section{Results and Discussion}

3.1. Pb Level in Rainwater. From the results of the examination of rainwater samples originating from West Kalimantan, Indonesia, with the research locations of Pontianak City and Kubu Raya, it is seen that the rainwater in these areas contain $\mathrm{Pb}$. In addition, $\mathrm{Pb}$ in rainwater is also found in the southeastern region of Nigeria and Australia. The trigger factor for the presence of $\mathrm{Pb}$ in rainwater in the region comes from environmental factors such as air pollution and rainwater collection through zinc roofs $[4,5]$. The results of the examination (Table 1) show that the highest $\mathrm{Pb}$ levels in rainwater that come into contact with the zinc roof found in the Central Siantan District of North Pontianak have an average concentration of $222 \mu \mathrm{g} / \mathrm{l}$ and the lowest concentration is found in Limbung village in Sungai Raya District with an average of $44.6 \mu \mathrm{g} / \mathrm{l}$. Meanwhile, the average $\mathrm{Pb}$ contained in rainwater that came into contact with the zinc roof before processing was $131.7 \mu \mathrm{g} / \mathrm{l}$, exceeding the permitted value set by the WHO Guideline for Drinking-Water Quality Guidelines (10 $\mu \mathrm{g} / \mathrm{l}(8.9))$. After applying mollusk sand filtration and absorption of activated carbon, the results showed that rainwater has met the requirements of drinking water, reaching a value of $0.71 \mu \mathrm{g} / \mathrm{l}$. The effectiveness produced for the treatment of $\mathrm{Pb}$ contained in rainwater is 99.47\%. Statistical tests showed that there were significant differences in the level of $\mathrm{Pb}$ in rainwater before and after treatment $(p \leq 0.001)$.

Plumbum $(\mathrm{Pb})$ in rainwater that touches zinc roofs in Pontianak and Kubu Raya districts before treatment shows that the average level is $131.7 \mu \mathrm{g} / \mathrm{l}$. This shows that the quality of rainwater stored directly from the zinc roof does not meet 
TABLE 1: Average $\mathrm{Pb}$ concentration in rainwater before and after treatment.

\begin{tabular}{|c|c|c|c|c|}
\hline City/regency area & Subdistrict/village & Before treatment $(\mu \mathrm{g} / \mathrm{l})$ & After treatment $(\mu \mathrm{g} / \mathrm{l})$ & Drinking water requirement \\
\hline \multirow[b]{2}{*}{ Pontianak } & Siantan Hulu & 201.3 & 0.75 & $0.01 \mathrm{mg} / \mathrm{l}(10 \mu \mathrm{g} / \mathrm{l})$ \\
\hline & Siantan Tengah & 222.0 & 0.77 & \\
\hline \multirow{2}{*}{ Kubu Raya } & Limbung village & 44.6 & 0.85 & \\
\hline & Kuala Dua village & 58.9 & 0.47 & \\
\hline Mean & & 131.7 & 0.71 & \\
\hline Median (min.-max.) & & $101.8(3.2-363.0)$ & $0.1(0.1-3.0)$ & \\
\hline SD & & 0.1046669 & 0.0001434 & \\
\hline$P^{\mathrm{a}}$ & & & $\leq 0.001^{*}$ & \\
\hline
\end{tabular}

Source: primary data; ${ }^{a} T$-test $(\alpha=5 \%) ;{ }^{*}$ significant at $p \leq 0.05$.

the drinking water quality requirements. $\mathrm{Pb}$ in rainwater is caused by the $\mathrm{Pb}$ layer on the zinc roof which is also soluble in acid rainwater. According to a research conducted in Australia, the $\mathrm{Pb}$ content is closely related to $\mathrm{Pb}$ which is used to coat zinc roofs $[4,21]$. Besides zinc roofing used, $\mathrm{Pb}$ in rainwater is also caused by environmental factors because the results of research conducted in Southeast Nigeria from 2007 to 2008 in seven target cities showed a high content of plumbum $(\mathrm{Pb})$. This is caused by car emissions and industrial waste [5]. Increased $\mathrm{Pb}$ rainwater occurs at the beginning and end of the year due to low rainfall, while in the middle of the year, it was relatively lower due to rainwater dilution. The high $\mathrm{Pb}$ content in rainwater is also supported by the nature of acid rain so that the $\mathrm{Pb}$ dissolution rate is greater [21].

$\mathrm{Pb}$ found in rainwater confirms that generally rainwater has relatively good (clean) quality for drinking water but has a tendency to get polluted when it is in the atmosphere and when it drops on the ground. The contamination which happens in the atmosphere can be caused by dust particles, microorganisms, and gasses such as $\mathrm{NO}_{x}, \mathrm{CO}_{x}$, and $\mathrm{SO}_{x}$. These pollutants are sourced from the emission of vehicles and industries and also can be sourced from the roof materials as the collector and container for rainwater $[10,11,13]$. The results of analysis from several countries such as Palestine and Australia mention that dust particles, heavy metals, and bird feces affect the physical quality of rainwater such as color and taste [22-24].

The presence of $\mathrm{Pb}$ in rainwater in Pontianak City is higher $(211.6 \mu \mathrm{g} / \mathrm{l})$ compared to $\mathrm{Pb}$ in rainwater in Kubu Raya Regency $(51.75 \mu \mathrm{g} / \mathrm{l})$. The fort is a rural area. This showed that the level of air pollution contributes to the presence of $\mathrm{Pb}$ in rainwater. Some physical, chemical, and biological air pollution parameters are quite high, for example, dust particles, $\mathrm{CO}$, and heavy metals such as $\mathrm{Pb}$. The emission particles are produced by vehicles and industries; especially in urban areas, $\mathrm{Pb}$ pollution will be greater [23-25].

There were sources of lead $(\mathrm{Pb})$ in rainwater stored from a roof. $\mathrm{Pb}$ found in rainwater is due to dust particles in the air which has lead and stick on the roof in urban areas and can be sourced from the combustion process of fuel from vehicles and industries [12]. Lead can also be sourced from dust particle contamination as a result of land clearing by fire for farming and planting purposes and from the materials used as roof to collect and store rainwater $[9,25]$.
The reason why $\mathrm{Pb}$ concentration found in rainwater is high is not only influenced by dust particles produced by land-clearing activities or fuel combustion but also influenced by the material used for collecting and storing the rainwater $[9,25]$. This can be seen from the results of examination of $\mathrm{Pb}$ concentration in rainwater on the zinc roof. The content of $\mathrm{Pb}$ found in the rainwater that came into contact with the zinc roof was higher than that found indirectly in stored rainwater, i.e., $131.7 \mu \mathrm{g} / \mathrm{l}$ and $109.7 \mu \mathrm{g} / \mathrm{l}$. The presence of $\mathrm{Pb}$ in rainwater that is accommodated through zinc roofs is caused by air pollution and is also caused by corrosion of the zinc roof due to acid rain. $\mathrm{Pb}$ as a zinc roof coating also dissolves in rainwater.

The high $\mathrm{Pb}$ dissolved in rainwater is also because of natural conditions in Pontianak and Kubu Raya which are the locations in the tropics and are positioned right on the equator; therefore, the sun always passes them throughout the year. Because of these conditions, Pontianak and Kubu Raya always get full sunshine throughout the year and rain all day, especially in October and March $[13,26]$. Therefore, air pollutants resulting from land-clearing and fuel combustion activities produce emissions of air pollutants such as tetraethyl lead (TEL) and tetramethyl lead [23]. Tetraethyl lead and tetramethyl lead particles will break in the air with the help of sunlight into monoethyl- $\mathrm{Pb}$, diethyl- $\mathrm{Pb}$, and triethyl- $\mathrm{Pb}$. These three organic $\mathrm{Pb}$ components are easily soluble in water. $\mathrm{Pb}$ in rainwater is not only related to a number of factors such as sunlight, air humidity, and $\mathrm{Pb}$ types that are produced from the breakdown process but are also influenced by acid-base rainwater. In general, rainwater is soft water with a fairly high acid level, $\mathrm{pH}<5$. Soft water and $\mathrm{pH}<5$ will cause $\mathrm{Pb}$ to have high solubility and increase its concentration; therefore, when rain falls, $\mathrm{Pb}$ will easily dissolve in rainwater and enter rainwater storage and is unacceptable or not suitable for consumption [27].

3.2. Rainwater Turbidity. In Table 2, it is shown that the average turbidity of the rainwater which came into contact with the tin roof before the treatment has the highest level which is found in the subdistrict of Siantan Hulu of Pontianak for 22.26 NTU, and after the treatment, it had been lowered to 9.84 NTU. Meanwhile, the average turbidity of rainwater which came into contact with a tin roof found in 40 houses is $20.0 \mathrm{NTU}$, and after treatment, the level had been lowered to 5.67 NTU. The turbidity level after 
TABLe 2: Average turbidity level in rainwater before and after treatment.

\begin{tabular}{|c|c|c|c|c|}
\hline City/regency area & Subdistrict/village & $\bar{X}$ before treatment $(\mathrm{NTU})$ & $\bar{X}$ after treatment (NTU) & Drinking water requirement \\
\hline \multirow{2}{*}{ Pontianak } & Siantan Hulu & 22.261 & 9.839 & $5 \mathrm{NTU}$ \\
\hline & Siantan Tengah & 21.572 & 7.872 & \\
\hline \multirow{2}{*}{ Kubu Raya } & Limbung village & 17.675 & 2.114 & \\
\hline & Kuala Dua village & 18.502 & 2.831 & \\
\hline Mean & & 20.00 & 5.67 & \\
\hline Median (min.-max.) & & $18.95(15.06-26.81)$ & $2.92(0.14-14.96)$ & \\
\hline $\mathrm{SD}$ & & 3.33 & 5.15 & \\
\hline$P^{\mathrm{a}}$ & & & $\leq 0.001^{*}$ & \\
\hline
\end{tabular}

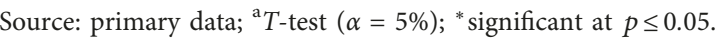

treatment of rainwater using a filtered tube has met the requirement for drinking water which is 5 NTU. The effectiveness level of turbidity reduction after treatment is $72 \%$. The statistic test has shown a significant difference in the turbidity of rainwater before and after treatment $(p<0.001)$.

Generally, turbidity in rainwater is caused by suspended solid substances, either inorganic or organic [28, 29]. The high level of turbidity shows that rainwater has been polluted physically, chemically, and biologically. Physical pollutants included animal waste (bird) and dust particles produced by land-clearing activity by fire in rice fields and plantation. Chemical pollutants from emission produced by the combustion process of fuel from vehicles and industries included chemical-contained tin roof material used to collect and store rainwater. Meanwhile, microbiological pollutants come from viruses and bacteria found in the air. because these pollutants and $\mathrm{Pb}$ used as zinc roof coatings result in high turbidity of rain water and are not suitable for consumption $[24,25]$.

3.3. $p H$ of Rain Water. It is known from the examination results in Table 3 that the lowest rainwater $\mathrm{pH}$ which came into contact the tin roof before treatment found in Siantan Hulu of Pontianak was an average of 4.62, and after the treatment, it had the highest escalation to 7.001; meanwhile, the average $\mathrm{pH}$ level of rainwater which came into contact with the tin roof before the treatment found in 40 houses was 5.16, and after treatment, it had increased to 6.95. Statistical tests showed that there were significant differences in the $\mathrm{pH}$ of rainwater before and after treatment $(p \leq 0.001)$.

Soft water such as rainwater with $\mathrm{pH}$ less than 5 will cause the level of metal solubility high, especially lead $(\mathrm{Pb})$ solubility. $\mathrm{Pb}$ solubility comes from the piping system and other metal substances; as it is used for the roof to collect and store rainwater, it will be corrosive and will dissolve in rainwater. Therefore, the low $\mathrm{pH}$ of rainwater $(\mathrm{pH}<5)$ will affect the solubility of poisonous metals such as $\mathrm{Pb}$, making the rainwater unfit to be consumed [14]. Based on the high level of $\mathrm{Pb}$, turbidity, and low $\mathrm{pH}$ found in rainwater, which is above the allowable value set the WHO, we need appropriate technology for the treatment.

Low $\mathrm{pH}$ in rainwater is influenced by air pollution from industries and land combustion. Air pollution is in the form of $\mathrm{CO}_{\mathrm{x}}, \mathrm{NO}_{\mathrm{x}}$, and $\mathrm{SO}_{\mathrm{x}}$ which results in acid rain [30]. The gas reacts with rainwater $\left(\mathrm{H}_{2} \mathrm{O}\right)$ to form carbonic acid $\left(\mathrm{H}_{2} \mathrm{CO}_{3}\right)$, sulfuric acid $\left(\mathrm{H}_{2} \mathrm{SO}_{4}\right)$, and nitric acid $\left.\left(\mathrm{H}_{2} \mathrm{NO}_{3}\right)[31,32]\right)$. Acidic rainwater will cause corrosiveness on the zinc roof and has a high solubility against heavy metals such as $\mathrm{Pb}$ [32] (Figure 3). This condition results in $\mathrm{Pb}$ being used as a zinc roof coating to dissolve in rainwater, and $\mathrm{Pb}$ particles released in the air that come from burning fuel are also dissolved in rainwater. So that in filtering rainwater before the process of absorbing activated carbon, it is necessary to increase $\mathrm{pH}$ to maximize the absorption process. Increasing $\mathrm{pH}$ is carried out using media that have alkaline compounds, such as mollusk sand which has $\mathrm{CaCO}$ [33] and activated carbon that has a $\mathrm{pH} 8$ and 9.5. In alkaline conditions, $\mathrm{OH}$ ions will be larger, resulting in deprotonated mollusk sands so that metal cations are bound. After going through the $\mathrm{Pb}$ activated carbon media, they will be absorbed by activated carbon [34].

3.4. $\mathrm{Pb}$ in Rainwater and Public Health. $\mathrm{Pb}$ is a heavy metal which has the highest affinity for sulfur and attacks its bonds the enzymes. As a heavy metal, $\mathrm{Pb}$ is classified as a hazardous pollutant [35]. $\mathrm{Pb}$ is present in water in the form of $\mathrm{Pb}$ $(\mathrm{OH})_{2} . \mathrm{Pb}$ metal is widely used in zinc coating industries and piping work. Leaded gasoline is the main source in the atmosphere and the face of the earth. Most $\mathrm{Pb}$ on the earth enters the natural aquatic system and accumulates, which can eventually enter the body of animals and humans. If absorbed into the human body, lead $(\mathrm{Pb})$ can cause children's intelligence to decline and body's growth to hamper and can even cause paralysis. Other symptoms of $\mathrm{Pb}$ metal poisoning are as follows: nausea, anemia, and abdominal pain [36].

There is a tendency between the levels of exposure to $\mathrm{Pb}$ in rainwater with $\mathrm{Pb}$ levels in urine for those who consume rainwater as their drinking water. Statistical analysis has shown that there is a correlation between exposures to $\mathrm{Pb}$ in rainwater and public health disorders. The higher the level of exposure to $\mathrm{Pb}$ in rainwater, the bigger the chances for the public to suffer health disorders by consuming rainwater $(r=0.3)$.

There is a tendency between the high level of $\mathrm{Pb}$ exposure in rain water and the high level of $\mathrm{Pb}$ in urine (health disorder) in public who consume rain water as their drinking water (Figure 4). There is also a meaningful correlation: a moderate correlation strength between the high level of $\mathrm{Pb}$ in rain water to the amount of $\mathrm{Pb}$ concentration found in urine in public health. Lead $(\mathrm{Pb})$ is toxic to the human body, 
TABLE 3: Rainwater $\mathrm{pH}$ before and after treatment.

\begin{tabular}{|c|c|c|c|c|}
\hline City/regency area & Subdistrict/village & $\mathrm{pH}$ before treatment & $\mathrm{pH}$ after treatment & Drinking water requirement \\
\hline \multirow[b]{2}{*}{ Pontianak } & Siantan Hulu & 4.626 & 7.001 & $6.5-8.5$ \\
\hline & Siantan Tengah & 4.937 & 6.981 & \\
\hline \multirow{2}{*}{ Kubu Raya } & Desa Limbung & 5.357 & 6.791 & \\
\hline & Desa Kuala Dua & 5.721 & 7.014 & \\
\hline Mean & & 5.16 & 6.95 & \\
\hline Median (min.-max.) & & $5.06(4.61-6.09)$ & $6.96(6.31-7.43)$ & \\
\hline Sd & & 0.52 & 0.21 & \\
\hline$P^{\mathrm{a}}$ & & & $\leq 0.001^{*}$ & \\
\hline
\end{tabular}

Source: primary data; ${ }^{\mathrm{a}} T$-test $(\alpha=5 \%) ;{ }^{*}$ significant at $p \leq 0.05$.

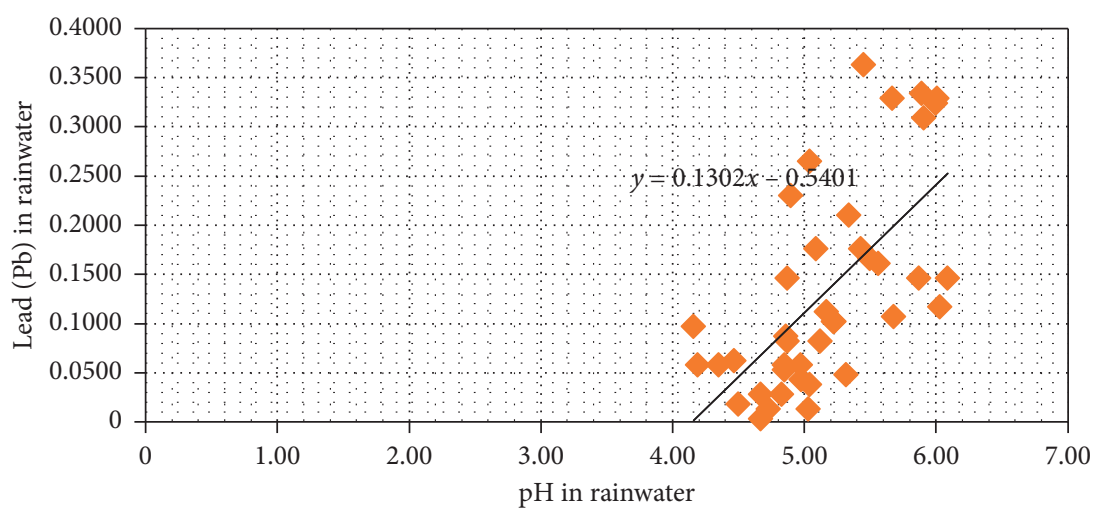

Series 1

— Linear (series 1)

Figure 3: $\mathrm{pH}$ of rainwater to $\mathrm{Pb}$ content in rainwater in West Kalimantan.

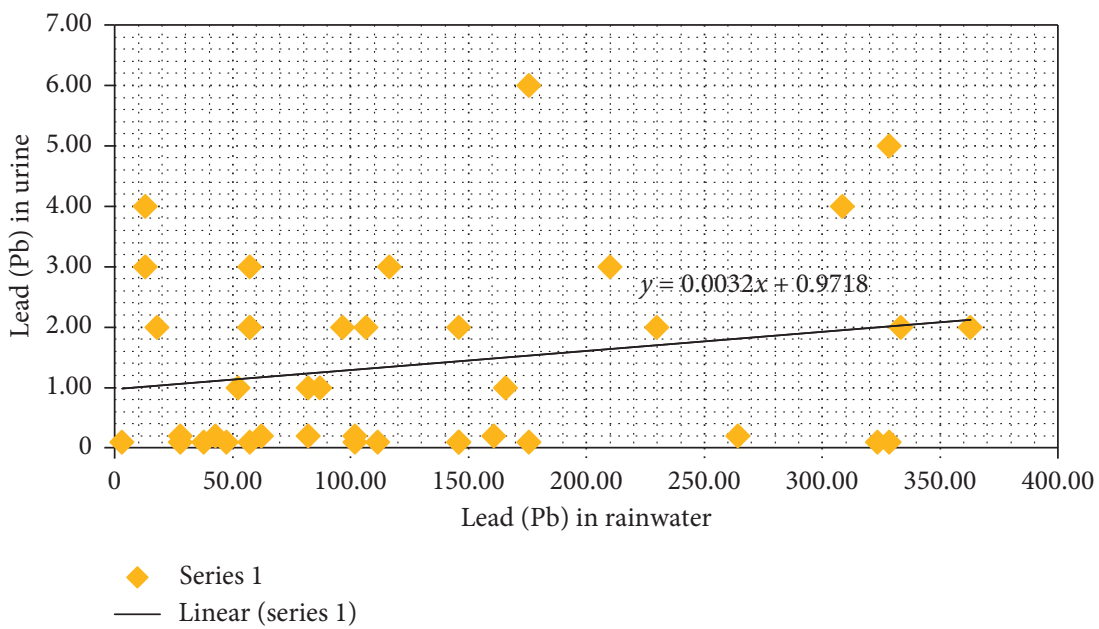

Figure 4: $\mathrm{Pb}$ levels in rainwater against $\mathrm{Pb}$ urine content (mean: 1.39; median: 1.00; SD: 1.54; min.: 1.00; max.: 6.00).

which is caused by food habits and consumption activities of food/drinks. $\mathrm{Pb}$ is not only known to be toxic but also can accumulate in the human body. Based on the results of research in Abuja, Nigeria, it is seen that the occupational exposure increases the level of lead in the blood, which consequently increases the health risk of the exposed people [37]. The exposure source and the high level of $\mathrm{Pb}$ concentrations are caused by toxication or health disorders among public. Research conducted in Riyadh shows that $\mathrm{Pb}$ concentration in domestic drinking water is higher than that in bottled drinking water and also that the concentration level of $\mathrm{Pb}$ in the blood of those who consumed domestic water is higher than that in those who consumed bottled drinking water [38]. 
Based on research in Poland, it is concluded that the road dust as a by-product of exhaust and nonexhaust emissions can be a major cause of systemic oxidative stress and multiple disorders. Substantial amounts of road dust are repeatedly suspended, in particular, at traffic signals and junctions where more braking is involved, causing a potential threat to pedestrians; especially, children HQ indices calculated for the analyzed traffic-related elements were all lower than 1.0, potentially indicating noncarcinogenic effect. The $\mathrm{HI}$ index for selected metals, for example, $\mathrm{Cd}, \mathrm{Cu}, \mathrm{Co}$, and $\mathrm{Pb}$, for adults fell within the safe value. However, in the case of children, the HI values exceeded the safe level of 1.0 for road dust, sludge from storm drains, and roadside topsoil in all investigated cities [39].

3.5. Rainwater Treatment. To decrease the content of $\mathrm{Pb}$ in water, especially in rainwater, we can use several methods: the timer setting for collecting and treatment by using the filtration method and absorption method using activated carbon. Filtration and absorption methods are usually used to process the ground water and underground water which have a high level of metals such as $\mathrm{Fe}, \mathrm{Hg}$, and $\mathrm{Pb}$. For that reason, treatment to reduce the content of $\mathrm{Pb}$ in rainwater is needed. The method used to decrease the pollutant level in rainwater is using a filtration tube combined with gravel, mollusk sand, and activated carbon.

The decrease in $\mathrm{Pb}$ concentration and turbidity level and an increase in $\mathrm{pH}$ happened after the substances or materials contained in rainwater passed through a filtration tube which consisted of activated carbon coconut shell granules, mollusk sand, and gravel. The tube length was $120 \mathrm{~cm}$ with $20 \mathrm{~cm}$ thick gravel, $35 \mathrm{~cm}$ thick mollusk sand, and $45 \mathrm{~cm}$ thick activated carbon granules. Mollusk sand media are generally used with a thickness of $20 \mathrm{~cm}$. However, the thicker the passive mollusk, the better it will reduce turbidity. The high level of turbidity found in rainwater is caused by dust particles including $\mathrm{Pb}$ particles, bird waste, and microorganisms, or it usually depends on the characteristic of pollutants in an area or a city. The mollusk sand medium filter in the tube will form a film layer that will function effectively in filtering the pollutant particles like dust, either metals such as $\mathrm{Pb}$ or nonmetals such as bacteria and viruses, and the color of rainwater.

The effectiveness degree of the mollusk sand filter is higher in decreasing $\mathrm{Pb}$ concentration and turbidity and in increasing the $\mathrm{pH}$ of rainwater compared to ordinary sand and activated carbon used for filtration; for example, river water treatment using quartz sand can increase $\mathrm{pH}$ by around $4.7 \%$ and rainwater treatment can increase $\mathrm{pH}$ by $2.9 \%$, while mollusk sand can increase $\mathrm{pH}$ in rainwater treatment by $26 \%$. Mollusk shell sand showed better function in increasing the rainwater $\mathrm{pH}$; this happened due to $\mathrm{CaO}$ (94.1\%), $\mathrm{Na}_{2} \mathrm{O}(1 \%)$, and $\mathrm{SiO}(1 \%)$ present in mollusk sand. Mollusk sand also absorbs heavy metals found in water and holds suspended materials, and thus mollusk sand is very useful and used as a filtration medium in water treatment $[28,29]$.

Shell is one of the mineral sources which come from sea creatures, and it can be been ground into small pieces and has high carbon. Minerals contained in the shell are variable and high; for example, calcium contained in the shell is $66.7 \%$, magnesium $22.28 \%$, and $\mathrm{SiO}_{2} 7.88 \%$. That is why minerals found in shells which naturally have attrition or decomposition can increase rainwater $\mathrm{pH}$ and their carbonate content can oxidize $\mathrm{Pb}$ in rainwater [40].

Rainwater is not always a good clean water source that is ready to be consumed; physically, it does not have color, taste, and clarity. Rainwater is affected by the area where the rain falls. In rural areas, rainwater could be polluted by waste produced by land-clearing activities, pesticides, and animal wastes, while in urban areas, rainwater could be polluted by chemical substances dissolved in water which are tasteless and colorless and cannot be seen. A chemical substance such as $\mathrm{Pb}$ could come from the materials such as roofs, paint, tin, tar, dust, and asbestos. $\mathrm{Pb}$ could also be produced from a volcanic eruption and gas emission from fuel combustion of vehicles and industries. Rainwater contamination is not only caused by chemical substances but also can be sourced from microorganic matters such as bacteria, virus, and parasite $[23,24]$.

Due to the varied pollutants found in rainwater, the turbidity level has increased. The turbidity level, especially in rainwater, can also be sourced from suspended solid substances, organic and inorganic substances, and bioorganisms such as bacteria, viruses, and parasites which are airborne pollutants [24]. To decrease or reduce airborne pollutants in rainwater, filtration method by applying mollusk sand and sorption of activated carbon of coconut shells are conducted. The filtration of rainwater is done by passing the rainwater through a porous medium for particle substances which cannot be separated by sedimentation process. Pollutants that escape from filtration during rainwater treatment can be handled using absorption process; therefore, the filtration method by applying mollusk sand and absorption of activated carbon was proven to decrease the rainwater turbidity level, whose average level before the treatment was 20 NTU, and after treatment, it was 5.67 NTU with effectiveness of $72 \%$ and has met drinking water need.

Rainwater treatment using the absorption process aims to decrease suspended organic and inorganic substances which escape from the filtration process; therefore, this process functions to decrease metal substances found in rainwater such as lead $(\mathrm{Pb})$. $\mathrm{Pb}$ concentration in rainwater which does not meet the requirement for drinking water has changed and is able to meet the requirement to be able to consume. The result of this research shows that $\mathrm{Pb}$ concentration in rainwater does not meet the requirement for drinking water, with the average $\mathrm{Pb}$ concentration found in rainwater before treatment being $131.7 \mu \mathrm{g} / \mathrm{l}$ and after treatment decreased to $0.69 \mu \mathrm{g} / \mathrm{l}$ with the effectiveness of $99.7 \%$.

The ability of activated carbon to absorb $\mathrm{Pb}$ substances in rainwater is because activated carbon has relatively big microspore and mesopore volume, which is very much possible to absorb pollutants (including $\mathrm{Pb}$ ) in inadequate amount. Activated carbon is one of the absorbents whose carbon atom structure is amorphous, mainly consisting of free carbon and also has a deep surface; therefore, it has a 
good absorption ability [41]. Therefore, to decrease the $\mathrm{Pb}$ concentration level and turbidity and to increase the $\mathrm{pH}$ of rainwater, it is best to apply the filtration process using mollusk sand in the filtering tube and also by applying absorption method of activated carbon. The result shows that the level of decreasing effectiveness for $\mathrm{Pb}$ is $99.47 \%$ and $72 \%$ turbidity and the $\mathrm{pH}$ increases, with an average of 5.16 before treatment and 6.95 after treatment and the effectiveness of $\mathrm{pH}$ increasing to $26 \%$. After the treatment, the $\mathrm{Pb}$ concentration level went down to $0.69 \mu \mathrm{g} / \mathrm{l}$, turbidity level to 5.6 NTU, and $\mathrm{pH}$ up to 6.95. This result has met the need for drinking water quality of $\mathrm{Pb}$ concentration level at $10 \mu \mathrm{g} / \mathrm{l}$, turbidity at $5 \mathrm{NTU}$, and $\mathrm{pH}$ level at 6.5-8.5 [14, 42].

Sorption between activated carbon and rainwater containing $\mathrm{Pb}$ is strongly influenced by the $\mathrm{pH}$ of rainwater [27]. Absorption by activated carbon carried out at high $\mathrm{pH}$ tends to provide optimum results because in alkaline conditions an oxide compound of $\mathrm{Pb}$ element will be sorbed by the sorbent. To increase the $\mathrm{pH}$ in acidic rainwater, mollusk sand filtration medium is used before sorption using activated carbon, which is where mollusk sand can increase the $\mathrm{pH}$ of rainwater.

Backwash is a method used in the treatment of filtration devices. Backwash must be carried out continuously at regular intervals to maintain the effectiveness of the filtration device $[43,44]$. The time period for the backwash has not yet been found to be explained in the literature. It has just been mentioned that the backwash indicator needs to be done. Backwash is done with the processed indicator which starts to become cloudy, and the effluent flow rate decreases to $30 \%$ or less from the initial value $[44,45]$. Saturation of filtration media depends on the intensity of use and the load of $\mathrm{Pb}$ rainwater contamination. If, after being linked, backwash processed results do not show differences with raw water, then the filter media must be replaced with new media. Backwash can be active because the bond that forms on the activated carbon and $\mathrm{Pb}$ is an irreversible reaction. $\mathrm{Pb}$ absorbed by activated carbon can be released again under pressure. The current given to release $\mathrm{Pb}$ ions with carbon and mollusk sand must be reversed.

\section{Practical Implications of This Study}

This study found that rainwater in the tropics experienced heavy metal pollution with pollutants such as lead $(\mathrm{Pb})$. Acid rain due to air pollution and the condition of the community using a zinc roof to hold rainwater aggravates the $\mathrm{Pb}$ level in rainwater. The $\mathrm{Pb}$ content in rainwater affects public health with early indications of $\mathrm{Pb}$ in the urine. This study also provides an alternative solution to the problem of providing clean drinking water by filtration by using mollusk sand media and activated carbon to eliminate this contamination. Other efforts can also be made by providing substitutes for $\mathrm{Pb}$-zinc roofing with an environmentally friendly roof for high air polluted areas.

This study has limitations on measuring the public health impact caused by exposure of drinking water to lead as far as the $\mathrm{Pb}$ content is present in urine. So it is necessary to further study the impact of exposure to $\mathrm{Pb}$ so that it can provide further information and other efforts in controlling these impacts.

\section{Conclusion}

West Kalimantan has experienced lead pollution $(\mathrm{Pb})$ in rainwater. The pollution of rainwater with heavy metals is not only caused by air pollution but also by the use of zinc roofs with $\mathrm{Pb}$ coatings to strengthen the bonds of zinc layers with iron layers. For purification of water contaminated with lead $(\mathrm{Pb})$, a simple filtration method using mollusk sand media and activated carbon can be used. For this reason, the need to reduce exposure of rainwater to lead is carried out by replacing roofs with non- $\mathrm{Pb}$-coated roofs and using filtration method as rainwater treatment before using rainwater as drinking water.

\section{Data Availability}

The data used to support the findings of this study are available from the corresponding author upon request.

\section{Conflicts of Interest}

The authors declare that there are no conflicts of interest regarding the publication of this article.

\section{Authors' Contributions}

All the authors collaborated in this work. Khayan conceptualized the study; Khayan, Adi, Indwiani, Sudarmajdi, and Tjut designed methodologies; Khayan and Adi performed formal analysis; Khayan wrote and prepared the original draft; and Khayan, Adi, Indwiani, Sudarmajdi, and Tjut wrote, edited, and reviewed the article.

\section{Acknowledgments}

The authors thank the Faculty of Medicine, Gadjah Mada University for Science, and Polytechnic of Health (POLTEKKES), Indonesia. The authors also extend their thanks to Pontianak District which always supports and has a complete laboratory for research.

\section{References}

[1] M. Kido, Y. M. Suhaemi, S. Sulastri et al., "Comparison of general water quality of rivers in Indonesia and Japan," Environmental Monitoring and Assessment, vol. 156, no. 1-4, pp. 317-329, 2009.

[2] W. Giesen, E. M. Macdonald, and J. Aglionby, "Introduction to danau sentarum national park, West Kalimantan, Indonesia," Borneo Research Bulletin, vol. 31, pp. 5-28, 2000.

[3] M. Kurasaki, D. I. Hartoto, T. Saito, and T. Iwakuma, "Metals in water in the Central Kalimantan," Bulletin of Environmental Contamination and Toxicology, vol. 65, no. 5, pp. 591-597, 2000.

[4] C. E. Chubaka, "Lead, zinc, copper, and cadmium content of water from south Australian rainwater tanks," International Journal of Environmental Research and Public Health, vol. 15, no. 7, p. 1551, 2018. 
[5] J. K. Nduka and O. E. Orisakwe, "Assessment of environmental distribution of lead in some municipalities of southeastern Nigeria," International Journal of Environmental Research and Public Health, vol. 7, no. 6, pp. 2501-2513, 2010.

[6] M. E Marlier, R. S. Defries, P. S. Kim, D. L. A. Gaveau, and S. N. Koplitz, "Regional air quality impacts of future fire emissions in Sumatra and Kalimantan," Environmental Research Letters, vol. 10, no. 5, pp. 1-11, article 054010.

[7] L. Tacconi, P. F. Moore, and D. Kaimowitz, "Fires in tropical forests-what is really the problem? Lessons from Indonesia," Mitigation and Adaptation Strategies for Global Change, vol. 12, no. 1, pp. 55-66, 2007.

[8] P. Taylor, R. Kim, S. Lee, Y. Kim, J. Lee, and S. Kim, "Pollutants in rainwater runoff in Korea: their impacts on rainwater utilization pollutants," pp. 37-41, 2010.

[9] R. Zhang, V. L. Wilson, A. Hou, and G. Meng, "Source of lead pollution, its influence on public," International Journal of Health Animal Science Food Safety, vol. 2, no. 1, pp. 18-31, 2015.

[10] L. H. Mason, J. P. Harp, and D. Y. Han, "Pb neurotoxicity: neuropsychological effects of lead toxicity," BioMed Research International, vol. 2014, Article ID 840547, 8 pages, 2014.

[11] G. Flora, D. Gupta, and A. Tiwari, "Toxicity of lead: a review with recent updates," Interdisciplinary Toxicology, vol. 5, no. 2, pp. 47-58, 2012.

[12] B. Fonseca, H. Maio, C. Quintelas, A. Teixeira, and T. Tavares, "Retention of $\mathrm{Cr}(\mathrm{VI})$ and $\mathrm{Pb}(\mathrm{II})$ on a loamy sand soil," Chemical Engineering Journal, vol. 152, no. 1, pp. 212-219, 2009.

[13] T. Budiwati, W. Setyawati, and D. A. Tanti, "Chemical characteristics of rainwater in Sumatera, Indonesia, during 2001-2010," International Journal of Atmospheric Sciences, vol. 2016, Article ID 1876046, 11 pages, 2016.

[14] V. S. Kale, "Consequence of temperature, ph, turbidity and dissolved oxygen water," Quality Parameters, vol. 3, no. 8, pp. 186-190, 2016.

[15] S. Triantafyllidou, Y. Lambrinidou, and M. Edwards, "LEAD $(\mathrm{Pb})$ Exposure through drinking water: lessons to be learned from recent," U. S. Experience, vol. 11, no. 3, pp. 341-348, 2009.

[16] P. B. Ryan, N. Huet, and D. L. MacIntosh, "Longitudinal Investigation of Exposure to Arsenic, Cadmium, and Lead in Drinking Water," Environmental Health Perspectives, vol. 108, no. 8, pp. 731-735, 2000.

[17] M. A. Tadda, A. Ahsan, A. Shitu, and M. Elsergany, "A review on activated carbon: process, application and prospects," Journal of Advanced Civil Engineering Practice and Research, vol. 2, no. 1, pp. 7-13, 2016.

[18] P. R. Gawande and J. Kaware, "Characterization and activation of coconut shell activated carbon research paper," International Journal of Engineering Science Invention, vol. 6, pp. 43-49, 2017.

[19] R. Islam, J. A. L. Foisal, M. Rahman, L. A. Lisa, and D. K. Paul, "Pollution assessment and heavy metal determination by AAS in waste water collected from Kushtia industrial zone in Bangladesh," African Journal of Environmental Science and Technology, vol. 10, no. 1, pp. 9-17, 2016.

[20] D. Bai, Q. Ying, N. Wang, and J. Lin, “Atomic absorption spectroscopy for the determination of heavy metals in polyethylene moulding materials using Anderson-Darling statistics and top-down uncertainty estimates," in Advances in Engineering Research, pp. 418-424, Nova Science Publishers, Hauppauge, NY, USA, July 2015.
[21] M. I. Magyar, A. R. Ladson, C. Diaper, and V. G. Mitchell, "Technical paper influence of roofing materials and lead flashing on rainwater tank contamination by metals," Australasian Journal of Water Resources, vol. 18, no. 1, 2014.

[22] A. K. Daoud, K. M. Swaileh, R. M. Hussein, and M. Matani, "Quality assessment of roof-harvested rainwater in the West Bank," Palestinian Authority, vol. 9, no. 3, pp. 525-533, 2011.

[23] P. K. Bharti, V. Singh, and P. K. Tyagi, "Assessment of rainwater quality in industrial area of rural Panipat (Haryana)," India, vol. 2, no. 3, pp. 219-223, 2017.

[24] H. W. Mielke and C. Patterson, "Dynamic geochemistry of tetraethyl lead dust during the 20th century: getting the lead in, out, and translational beyond," International Journal of Environmental Research and Public Health, vol. 15, no. 5, p. 860, 2018.

[25] S. Tiwari, I. P. Tripathi, M. Gandhi, C. Gramoday, and H. Tiwari, "Effects of lead on environment," International Journal of Emerging Research in Management and Technology, vol. 2, no. 6, 2013.

[26] C. Payus, K. J. Meng, N. Resources, E. Science, and N. Resources, "Consumption of rainwater harvesting in terms of water quality," International Journal of GEOMATE, vol. 9, no. 2, pp. 1515-1522, 2015.

[27] M. A. Kashem and B. R. Singh, "Metal availability in contaminated soils: I. Effects of flooding and organic matter on changes in Eh, $\mathrm{pH}$ and solubility of $\mathrm{Cd}, \mathrm{Ni}$ and $\mathrm{Zn}$," Nutrient Cycling in Agroecosystems, vol. 61, no. 3, pp. 247-255, 2001.

[28] M. Sillanpää, M. C. Ncibi, A. Matilainen, and M. Vepsäläinen, "Removal of natural organic matter in drinking water treatment by coagulation: A comprehensive review," Chemosphere, vol. 190, pp. 54-71, 2018.

[29] I. Journal, R. Energy, E. E. Issn, C. Engineering, and K. Email, "A study of coconut shell-activated carbon for filtration and its comparison with sand filtration,” vol. 2, no. 3, pp. 3-6, 2014.

[30] V. Velikova, I. Yordanov, and A. Edreva, "Oxidative stress and some antioxidant systems in acid rain-treated bean plants," Plant Science, vol. 151, no. 1, pp. 59-66, 2000.

[31] F. C. Menz and H. M. Seip, "Acid rain in Europe and the United States: an update," Environmental Science \& Policy, vol. 7, no. 4, pp. 253-265, 2004.

[32] R. A. J. Bogan, S. Ohde, T. Arakaki, I. Mori, and C. W. McLeod, "Changes in rainwater ph associated with increasing atmospheric carbon dioxide after the industrial revolution," Water, Air, and Soil Pollution, vol. 196, no. 1-4, pp. 263-271, 2009.

[33] A. J. Awang-Hazmi, A. B. Z. Zuki, M. M. Noordin, A. Jalila, and Y. Norimah, "Mineral composition of the cockle (Anadara granosa) shells of west coast of Peninsular Malaysia and it's potential as biomaterial for use in bone repair," Journal of Animal and Veterinary Advances, vol. 6, no. 5, pp. 591-594, 2007.

[34] P. Matter, L. Zhang, and U. Ozkan, "The role of nanostructure in nitrogen-containing carbon catalysts for the oxygen reduction reaction," Journal of Catalysis, vol. 239, no. 1, pp. 83-96, 2006.

[35] A. A. Patunru, "Access to safe drinking water and sanitation in Indonesia," Asia \& the Pacific Policy Studies, vol. 2, no. 2, pp. 234-244, 2015.

[36] H. Herawati, "Impact of climate change on streamflow in the tropical lowland of Kapuas River, West Borneo, Indonesia," Procedia Engineering, vol. 125, pp. 185-192, 2015. 
[37] L. A. Alli, "Blood level of cadmium and lead in occupationally exposed persons in Gwagwalada, Abuja, Nigeria," Interdisciplinary Toxicology, vol. 8, no. 3, pp. 146-150, 2015.

[38] A. M. Al-othman, Z. A. Al-othman, G. E. El-Desoky et al., "Lead in drinking water and human blood in Riyadh City, Saudi Arabia," Arabian Journal of Geosciences, vol. 6, no. 10, p. 4091, 2013.

[39] E. Adamiec, "Road environments: impact of metals on human health in heavily congested cities of Poland," International Journal of Environmental Research and Public Health, vol. 14, no. 7, p. 697, 2017.

[40] S. Nazahiyah, B. T. E. Rahmat, Z. Ali, and S. Musa, "Treatment of rainwater quality using sand filter," in Proceedings of International Conference on Environment, vol. 2008, Penang, Malaysia, December 2008.

[41] I. Adedayo and I. Anthony, "Comparison of the adsorptive capacity of raw materials in malting activated carbon filter for purification of polluted water for drinking," ARPN Journal of Science and Technology, vol. 2, no. 9, pp. 754-760, 2012.

[42] N. Rahmanian, S. Hajar, B. Ali, M. Homayoonfard, N. J. Ali, and M. Rehan, "Analysis of physiochemical parameters to evaluate the drinking water quality in the state of perak," Journal of Chemistry, vol. 2015, Article ID 716125, 10 pages, 2015.

[43] J. Niu, I. Kasuga, F. Kurisu, and H. Furumai, "Effects of backwashing on granular activated carbon with ammonium removal potential in a full-scale drinking water purification plant," Water, vol. 10, no. 12, p. 1830, 2018.

[44] P Laurent, A Kihn, A Andersson, and P Servais, "Impact of backwashing on nitrification in the biological activated carbon filters used in drinking water treatment," Environ Technology, vol. 24, no. 3, pp. 277-287, 2008.

[45] S. Park, J.-S. Kang, J. Lee, T.-K.-Q. Vo, and H.-S. Kim, "Application of physical and chemical enhanced backwashing to reduce membrane fouling in the water treatment process using ceramic membranes," Membranes, vol. 8, no. 4, p. 110, 2018. 


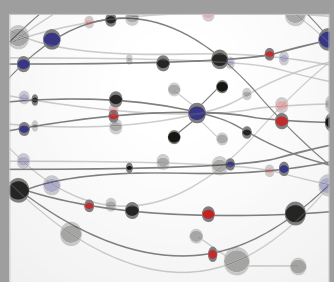

The Scientific World Journal
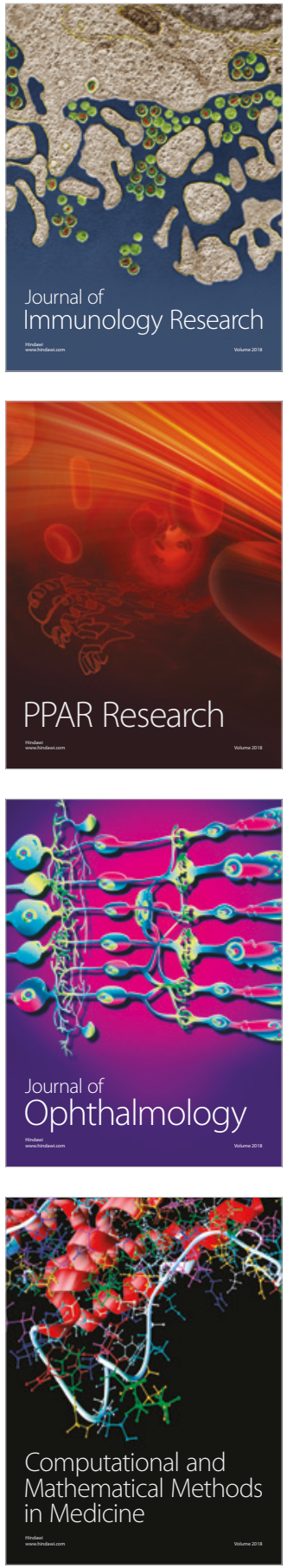

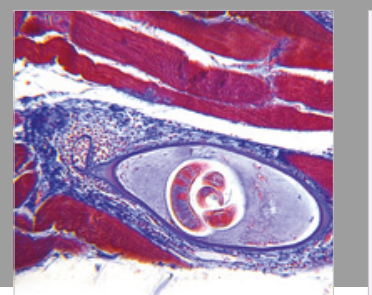

Gastroenterology Research and Practice

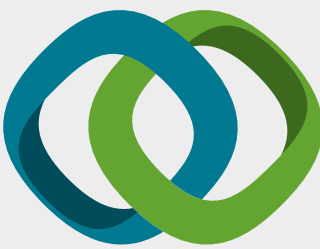

\section{Hindawi}

Submit your manuscripts at

www.hindawi.com
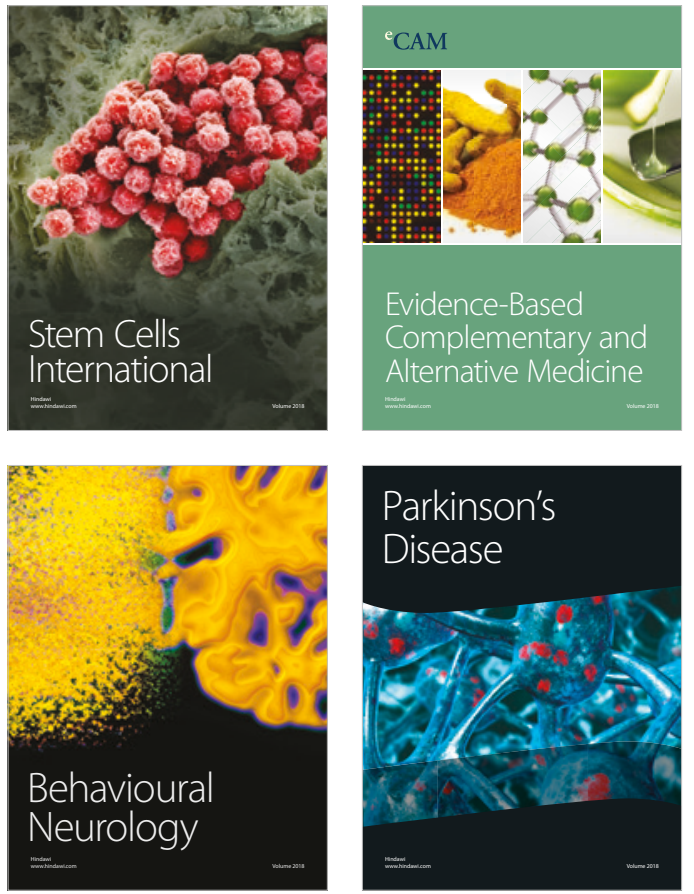

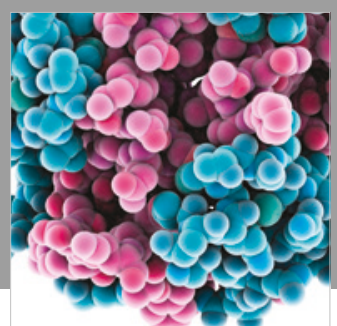

ournal of

Diabetes Research

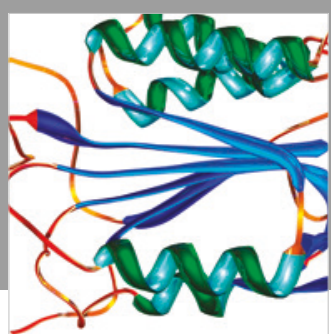

Disease Markers
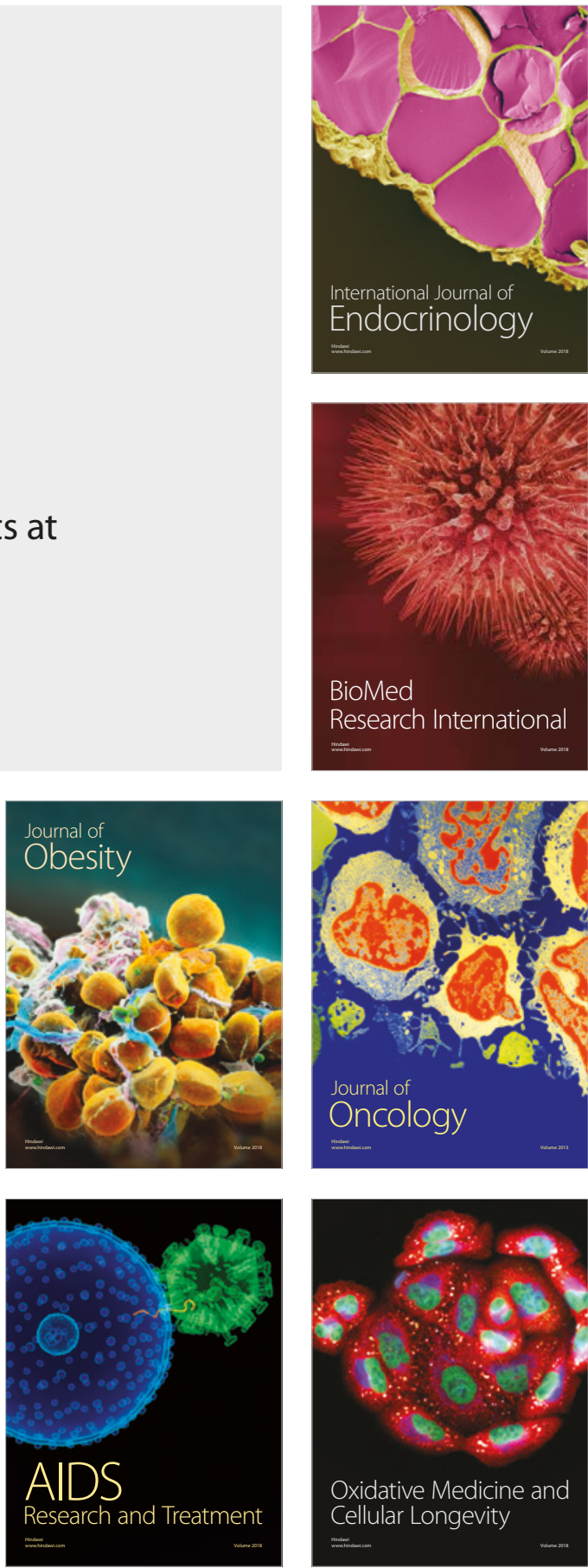